ISLAMIC BANKING: Jurnal Pemikiran dan Pengembangan Perbankan Syariah, Volume 7 Nomor 2 Edisi Februari 2022

\title{
PROGRAM "YUK NABUNG SAHAM" DAN REKSADANA DALAM PERSFEKTIF USAHA KECIL MENENGAH (UKM) SEBAGAI ALTERNATIF PEMILIHAN INVESTASI DAN PENINGKATAN PENDAPATAN DI KOTA PRABUMULIH PADA MASA PANDEMI COVID-19
}

\author{
Zakaria Harahap \\ STIE Prabumulih \\ Email: Zakariaharahap888@gmail.com \\ Ajabar \\ STIE Prabumulih \\ Email: ajabarholan@gmail.com
}

\begin{abstract}
To increase the number of domestic investors in the Capital Market, the Ministry of Finance in collaboration with the IDX and the Financial Services Authority (OJK) launched the "Yuk Nabung Saham" Program and the Capital Market School (SPM) targeting all campuses and all levels of society to have the opportunity to invest in the IDX. Various regulations and simplifications were made by the Government including free SPM, opening Securities and mutual fund accounts for only Rp. 100 thousand, and an online account opening system. Good news heard in the stock market. The socialization of the program was considered successful with the continued growth in the number of investors. PT. The Indonesian Central Securities Depository noted that the number of investors continued to grow until the end of September 2020 , the number of investors in the capital market rose $39.9 \%$ year to year (ytd) to 3.23 million investors. In fact, if we look at 2017 the figure is still 1.12 million. This number is predicted to continue to grow to 3.5 million investors by the end of 2020. This shows the increasing confidence of investors, both domestic and foreign investors, even during the current Covid-19 pandemic. This increase in 2020 is an increase beyond expectations. In fact, at this time when almost all economic sectors experienced a decline in income, the growth of investors actually increased sharply. Interestingly, from the demographic side of retail investors, $47.57 \%$ are dominated by the millennial generation or under 30 years of age. However, on the other hand, the SME sector, which is one of the main pillars of the economy that is able to absorb $97 \%$ of employment in Indonesia, is still not familiar with and invests in the Capital Market. The surprising news came from the survey results of the Ministry of Cooperatives and SMEs. The corona virus outbreak caused 47 percent to go bankrupt and KADIN predicts the number of unemployed to reach 13 million people due to the pandemic. Currently, SMEs are the worst sector and receive the most assistance from the government, including SME BLT, credit relaxation, tax incentives, etc. to save the SME sector. The main problems that are often faced by SMEs are capital and lack of investment literacy. With the phenomenon of this pandemic condition, researchers want to find out whether the "Yuk Nabung Saham" program and mutual funds can be a solution to the problems of the SME sector and increase the income of SMEs. The
\end{abstract}


purpose of this study is to examine whether the "Yuk Nabung Saham" and Mutual Fund programs are an alternative investment choice and increase income in Prabumulih City during the Covid-19 Pandemic. The research method used is a survey method, the selection of the population is determined intentionally (purposive sampling). The population of all SME actors, a population of 7,781 in Prabumulih City, samples were taken using the slovin method. So the sample that will be used in this study is as many as 99 respondents who represent the population selected at random according to the existing sampling procedure. From the output model summary, the determination table above gives an $R$ Square of 0.836. This shows that the variable Saving Mutual Funds Shares, Choosing Investment Alternatives Simultaneously the percentage of the contribution of the influence of the independent variable has an effect on the dependent variable (increase in income), amounting to $16.4 \%$. Or the independent variable (Saving Mutual Fund Shares, Choosing Investment Alternatives) is able to explain $83.6 \%$ of the dependent variable (increase in income), while the remaining $16.4 \%$ is influenced or explained by other variables not examined in this study.

Keywords: Saving Mutual Fund Shares, Choosing Alternative Investments and Increasing Income

Abstrak Untuk meningkatkan jumlah investor domestik di Pasar Modal Kementerian Keuangan bekerjasama dengan BEI dan Otorita Jasa Keuangan (OJK) meluncurkan Program "Yuk Nabung Saham" dan Sekolah Pasar Modal (SPM) dengan sasaran seluruh kampus dan semua lapisan masyarakat agar dapat memiliki kesempatan berinvestasi di BEI. berbagai regulasi dan simliplikasi dibuat Pemerintah diantaranya SPM gratis, membuka rekening Efek dan reksadana hanya dengan $\mathrm{Rp} 100$ ribu, dan sistem pembukaan rekening online. Berita baik terdengar di pasar modal. Sosialisasi Program tersebut dinilai berhasil dengan terus bertumbuhnya jumlah investor. PT. Kustodian Sentral Efek Indonesia mencatatkan jumlah investor terus bertumbuh sampai dengan akhir September 2020 jumlah investor di pasar modal naik $39.9 \%$ secara year to year (ytd) menjadi 3.23 juta investor. Padahal kalau kita lihat di tahun 2017 angkanya masih 1.12 juta. Jumlah tersebut diprediksi terus bertambah hingga 3.5 juta investor pada akhir tahun 2020. Ini menunjukkan semakin tingginya kepercayaan investor baik investor domestik ataupun investor asing walaupun di saat kondisi masa pandemi Covid-19 sekarang ini. Peningkatan di tahun 2020 ini merupakan peningkatan di luar ekspektasi. Padahal di masa saat ini ketika hampir semua sektor ekonomi mengalami penurunan pendapatan malah justru pertumbuhan investor meningkat tajam. Menariknya dari sisi demografi investor ritel tersebut sebanyak 47.57\% didominasi dari kalangan generasi milenial atau berusia dibawah 30 Tahun. Namun, di sisi lain sektor UKM yang menjadi salah satu pilar utama penggerak perekonomian yang mampu menyerap 97\% lapangan kerja di Indonesia, masih belum banyak mengenal dan berinvestasi di Pasar Modal. Kabar mengejutkan datang dari hasil suvei Kementerian Koperasi dan UKM. Wabah virus corona menyebabkan 47 persen bangkrut dan KADIN memprediksi jumlah pengangguran mencapai 13 juta orang akibat pandemi. Saat ini UKM justru menjadi sektor yang terpuruk dan paling banyak menerima bantuan dari Pemerintah diantaranya BLT UKM, rileksasi kredit, insentif pajak, dsb. demi penyelematan sektor UKM. Masalah utama yang sering dihadapi UKM adalah permodalan dan minimnya literasi investasi. Dengan adanya fenomena kondisi pandemi ini peneliti ingin mengetahui apakah program "Yuk Nabung Saham" dan reksadana dapat menjadi salah satu solusi dari permasalahan sektor UKM dan peningkatan pendapatan UKM. Adapun tujuan dari penelitian ini untuk meneliti apakah program "Yuk Nabung Saham" dan Reksadana sebagai alternatif pemilihan investasi dan peningkatan pendapatan di Kota Prabumulih pada masa Pandemi Covid-19. Metode Penelitian yang digunakan adalah metode survey, pemilihan populasi ditentukan dengan sengaja (purposive 
ISLAMIC BANKING: Jurnal Pemikiran dan Pengembangan Perbankan Syariah, Volume 7 Nomor 2 Edisi Februari 2022

sampling). Populasi seluruh pelaku UKM populasi yang berjumlah 7.781 di Kota Prabumulih sampel diambil dengan menggunakan metode slovin. Jadi sampel yang akan digunakan dalam penelitian ini adalah sebanyak 99 responden yang mewakili populasi yang dipilih secara acak sesuai dengan prosedur pengambilan sampel yang ada. Dari output model summary didapatkan tabel determinasi yang memberikan $R$ Square sebesar 0,836. Hal ini menunjukan bahwa variabel Nabung Saham Reksadana, Memilih alternatif Investasi secara simultan persentase sumbangan pengaruh variabel independen mempunyai pengaruh terhadap variabel dependen (peningkatan pendapatan), sebesar 16,4\%. Atau variabel independen (Nabung Saham Reksadana, Memilih alternatif Investasi) mampu menjelaskan sebesar 83,6\% terhadap variabel dependen (peningkatan pendapatan), sedangkan sisanya 16,4\% dipengaruhi atau dijelaskan oleh variabel lain yang tidak diteliti dalam penelitian ini.

Kata Kunci; Nabung Saham Reksadana, Memilih Alternatif Investasi dan Peningkatan Pendapatan.

\section{Dasar Pemikiran}

Pasar modal Indonesia merupakan salah satu industri pasar modal yang memiliki return investasi terbesar di dunia. Tidak heran porsi kepemilikan saham investor asing terhadap perusahaan-perusahaan baik perusahaan BUMN maupun Perusahaan Swasta masih sangat mendominasi. Untuk mengurangi ketergantungan Pasar modal dengan investor asing dan meningkatkan jumlah investor dalam negeri maka Pemerintah meluncurkan Program "Yuk Nabung Saham” dan Sekolah Pasar Modal. Program ini dinilai cukup efektif meningkatkan jumlah investor di Indonesia. Tahun 2020 jumlah investor mencapai 4.3 juta investor yang dua tahun sebelumnya hanya 1,6 juta Investor. Sosialisasi Program Yuk Nabung Saham dan sekolah Pasar Modal yang dilauncing Pemerintah cukup efektif meningkatkan jumlah investor. Namun Pandemi Covid-19 sangat memukul perekonomian Indonesia. Dari Kajian yang dibuat oleh Kementerian Keuangan menunjukkan bahwa pandemi Covid-19 memberikan implikasi negatif bagi perekonomian domestik seperti penurunan konsumsi dan daya beli masyarakat, penurunan kinerja perusahaan, ancaman pada sektor perbankan dan keuangan, serta eksistensi UKM. Masalah umum yang dihadapi sektor UKM adalah permodalan dan minimnya leterasi tentang investasi.

Kota Prabumulih adalah kota Perlintasan yang lokasinya 120 KM dari Kota Palembang. Lokasinya strategis sebagai penghubung jalan lintas Barat Sumatera. Sektor Pertanian adalah salah satu sumber penghasilan utama penduduknya selain itu bekerja di sektor tambang dan perdagangan. Penduduk Kota Prabumulih sudah mengenal 
investasi dengan sistem konvensional. Mereka berinvestasi dengan membeli kebun karet atau kebun sawit dan sebagian berinvestasi dengan emas perhiasan. Sistem investasi tradisional berdampak pada UKM yang ada di Kota Prabumulih. Masih banyak UKM yang belum mengenal investasi di Pasar modal. Mereka ikut berinvestasi dengan membeli kebun karet dan sawit dan juga berinvestasi emas sebagai bentuk tabungan jangka pendek.

Akibatnya ketika terjadi pandemi Covid-19 banyak UKM yang tutup. Dari total jumlah UKM 7.781 di Kota Prabumulih hampir 50 persen tutup karena merugi dan keterbatasan modal. Sementara investasi kebun yang dimiliki tidak likuid akibatnya sulit untuk dijual karena harga komoditas karet dan sawit yang terus turun. Kalupun ada pembeli maka biasanya harga akan jauh di bawah harga pasar. Sementara investasi emas perhiasan sifatnya jangka pendek dan konsumtif seperti membeli kendaraan.

Pemerintah sudah banyak memberikan kebijakan dan stimulan yang mendorong sektor UKM agar lebih cepat berkembang dari sisi permodalan dan kebijakan. Target Pemerintah Dengan banyaknya UKM yang menjadi perusahaan go public di Bursa Efek Indonesia maka akan semakin luas akses permodalan dan akselerisasi pertumbuhan UKM semakin cepat sehingga semakin banyak tenaga kerja yang terserap.

Dengan adanya permasalahan ini peneliti ingin mengetahui seberapa besar Program "Yuk Nabung Saham" dan Reksadana menjadi solusi terhadap masalah UKM di Kota Prabumulih. Tujuan dari penelitian ini guna menganalisa program "Yuk Nabung Saham" Dan Reksadana apakah berimplikasi sebagai aternatif pemilihan Investasi Sektor UKM di Kota Prabumulih. Selain itu. Maksud dari penelitian ini untuk memberikan gambaran mengenai kebijakan dan stategi apa yang dapat ditempuh sebagai pelengkap kebijakan tersebut.

Setalah melakukan studi litelatur serta observasi terhadap permasalahan yang dihadapi UKM. Maka dapat dikatakan penelitian yang dilakukan penulis tergolong unik, memiliki unsur kebaruan dan merupakan pengembangan penelitian PDP sebelumnya. Penelitian ini masih tergolong langka karena memotret fenomena terkini. Sehingga dapat diajukan sebagai kerangka acuan penelitian selanjutnya. 
ISLAMIC BANKING: Jurnal Pemikiran dan Pengembangan Perbankan Syariah, Volume 7 Nomor 2 Edisi Februari 2022

\section{TINJAUAN PUSTAKA}

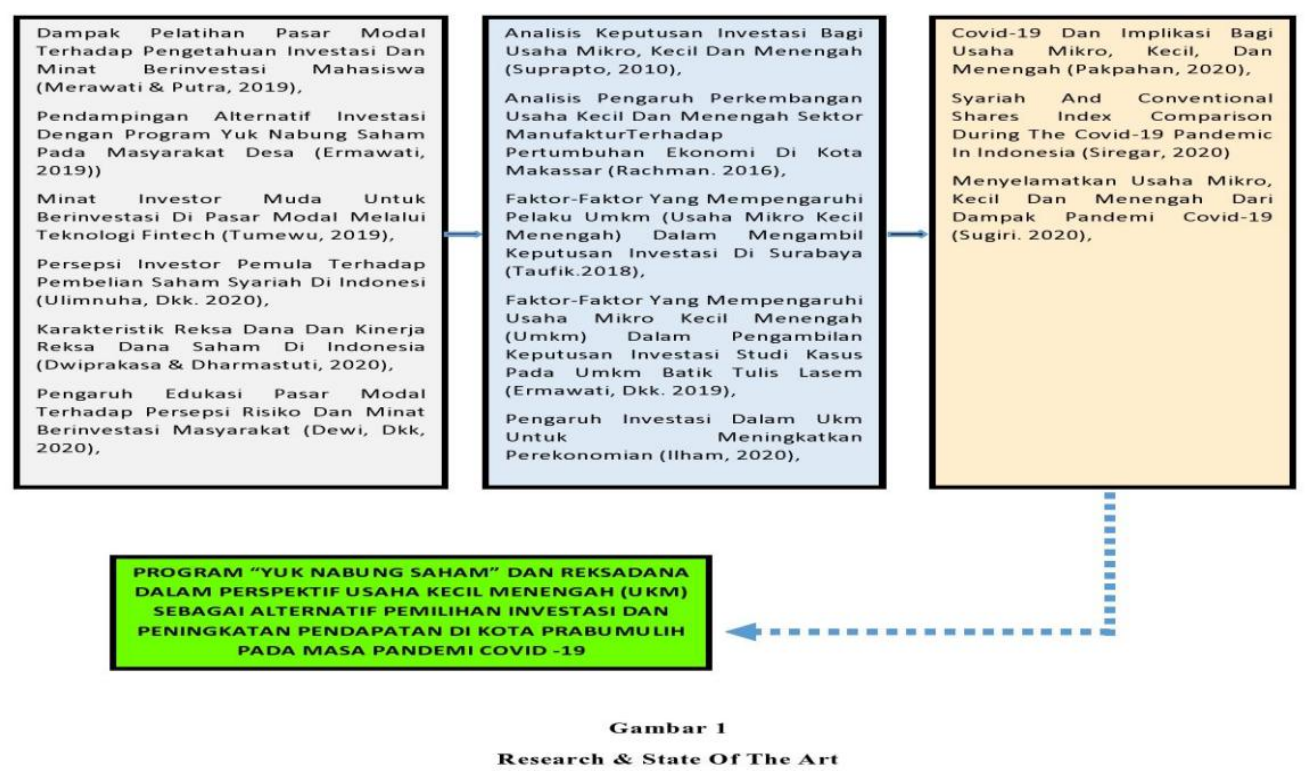

Berdasarkan Uraian penjelasan tabel di atas, dapat dilihat perbedaan penelitian ini dengan 14 penelitian sebelumnya. Dimana peneliti hendak mengetahui bagaimana dampak program "Yuk Nabung Saham"dan Reksadana dalam persfektif UKM sebagai alternatif pemilihan investasi dan peningkatan pendapatan di Kota Prabumulih pada masa pandemi Covid-19. Apakah investasi di pasar modal dapat dijadikan alternatif keputusan investasi yang dapat membantu permasalahan permodalan yang dihadapi UKM dan dapat meningkatkan pendapatan UKM pada masa Covid-19.

Menurut Bursa Efek Indonesia program "Yuk Nabung Saham" merupakan kampanye yang diselenggarakan oleh PT Bursa Efek Indonesia (BEI) untuk mengajak masyarakat sebagai calon investor untuk berinvestasi di pasar modal dengan membeli saham secara rutin dan berkala

Kampanye ini dimaksudkan agar merubah kebiasaan masyarakat Indonesia dari kebiasaan menabung menjadi berinvestasi, sehingga masyarakat Indonesia mulai bergerak dari saving society menjadi investing society. Pasar Modal memiliki peran penting bagi perekonomian suatu negara karena pasar modal menjalankan dua fungsi, yaitu pertama sebagai sarana bagi pendanaan usaha atau sebagai sarana bagi perusahaan untuk mendapatkan dana dari masyarakat pemodal/investor (www.idx.co.id). 
Menurut Tandio \& Widanaputra (2016) pelatihan pasar modal mempunyai pengaruh terhadap minat berinvestasi. Seorang akan lebih tertarik berinvestasi jika pemahaman tentang pasar modal lebih luas dan minat investasi di pasar modal akan meningkat seiring dengan meningkatnya edukasi dan persepsi. Namun sebaliknya pelatihan pada pasar modal belum mampu membagikan akibat yang positif serta signifikan terhadap atensi investasi (Merawati dan Putra, 2015).

Menurut Darmadji \& Fakhruddin (2012) saham (stock) merupakan tanda penyertaan atau pemilikan seseorang atau badan dalam suatu perusahaan atau perseroan terbatas. Saham berwujud selembar kertas yang menerangkan bahwa pemilik kertas tersebut adalah pemilik perusahaan yang menerbitkan surat berharga tersebut. Saham merupakan pesan berharga bagaikan ciri fakta kepemilikan ataupun penyertaan dari perorangan ataupun lembaga dalam sesuatu industri (Anoraga dan Pakarti, 2006).

Reksadana merupakan salah satu alternatif investasi bagi investor yang tidak memiliki banyak waktu, pengetahuan, dan keahlian untuk menghitung risiko investasi yang dilakukan. Qamruzzaman (2014) menyatakan bahwa reksa dana memiliki keuntungan dalam hal variasi, fleksibilitas, diversifikasi, dan likuiditas.

\section{Indikator Program Yuk Nabung Saham dan Reksadana}

Menurut Tando dan Widanaputra (2016)Yuk Nabung Saham merupakan kampanye yang diselenggarakan oleh PT Bursa Efek Indonesia (BEI) untuk mengajak masyarakat sebagai calon investor untuk berinvestasi di pasar modal dengan membeli saham secara rutin dan berkala (BEI, 2019).

Menurut Undang-Undang Nomor 20 Tahun 2008, Usaha Kecil dan Menengah (UKM) adalah jenis usaha kecil yang memiliki kekayaan bersih paling banyak Rp 200.000.000 tidak termasuk tanah dan bangunan tempat usaha. Dan usaha yang berdiri sendiri. Indonesia yang didominasi UKM perlu memberikan perhatian khusus terhadap sektor ini karena kontribusi UKM terhadap perekonomian nasional yang cukup besar (Pakpahan, 2020). Setidaknya terdapat tiga peran UKM yang sangat penting dalam kehidupan masyarakat kecil yakni sarana mengentaskan masyarakat dari jurang kemiskinan, sarana untuk meratakan tingkat perekonomian rakyat kecil, memberikan devisa bagi negara (Prasetyo \& Huda, 2019) Sampai dengan 17 April 2020, sebanyak 
ISLAMIC BANKING: Jurnal Pemikiran dan Pengembangan Perbankan Syariah, Volume 7 Nomor 2 Edisi Februari 2022

37.000 pelaku UKM melaporkan diri kepada Kementerian Koperasi dan UKM terdampak pandemi Covid-19 (Setiawan, 2020). Menurut rilis data tersebut, kesulitan yang dialami oleh UKM selama pandemi itu terbagi dalam empat masalah. Pertama, terdapat penurunan penjualan karena berkurangnya aktifitas masyarakat di luar sebagai konsumen. Kedua, kesulitan permodalan karena perputaran modal yang sulit sehubungan tingkat penjulan yang menurun. Ketiga, adanya hambatan distribusi produk karena adanya pembatasan pergerakan penyaluran produk di wilayah-wilayah tertentu. Keempat, adanya kesulitan bahan baku karena sebagai UKM menggantungkan ketersediaan bahan baku dari sektor industri lain (Sugiri. D. 2020)

Investasi ditanamkan perusahaan-perusahaan dalam memperoleh laba sebesarbesarnya (Aziz, 2010). Faktor yang mempengaruhi minat berinvestasi termasuk berinvestasi secara online. Diantaranya adalah Financial Literacy, Personal Interest, Environment (Tumewu, 2019). Untuk itu diperlukan pengetahuan keuangan atau literasi keuangan yang baik sebelum melakukan investasi (Putri, et.al.2019). Sedangkan pengambilan keputusan investasi adalah keputusan yang diambil oleh UKM, apakah akan menambah modal usaha atau tidak dengan alasan untuk memperoleh laba yang lebih tinggi di masa datang. Keputusan yang diambil UKM harus tepat, sekali salah keputusan akan berakibat maju mundurnya usaha yang sedang dihadapi (Ermawati, 2019).

\section{Metode Penelitian}

\section{Desain Penelitian}

Desain penelitian yang digunakan dalam penelitian ini adalah analisis deskritif yang dibantu dengan metode kualitatif dengan pendekatan kuantitatif.

\section{Jenis Penelitian}

Metode yang digunakan dalam penelitian ini adalah metode kuantitatif. Metode kuantitatif adalah metode yang digunakan untuk penyajian hasil penelitian dalam bentuk angka-angka atau statistik. Metode kuantitatif digunakan untuk menguji hipotesis. Penelitian ini dimaksudkan untuk mengetahui hubungan program "Yuk Nabung Saham" dan Reksadana, terhadap alternatif pemilihan investasi pada UKM Kota Prabumulih. 


\section{Waktu Penelitian}

Penelitian ini dilaksanakan pada UKM Kota Prabumulih, Waktu penelitian dilaksanakan dari bulan Januari sampai dengan bulan Agustus 2021.

\section{Populasi Dan Sampel}

Populasi dalam penelitian ini adalah semua UKM di Kota Prabumulih sebanyak 7.781 Metode penentuan sampel yang digunakan adalah purposive sampling dengan pertimbangan responden yang merupakan influencer/ decider dengan penarikan sampel menggunakan rumus Slovin (Umar, 2013) yaitu sebesar 99 responden

\section{Jenis Data}

Adapun jenis data yang digunakan dalam skripsi ini adalah : Data kualitatif, Data kuantitatif

\section{Sumber Data}

Untuk memperoleh data yang akurat penelitian ini menggunakan dua macam data yaitu data primer, data sekunder.

\section{Teknik Pengumpulan Data}

Adapun teknik dalam pengumpulan data penelitian ini meliputi sebagai berikut : wawancara, observasi, studi pustaka, kuesioner atau angket.

\section{Variabel Penelitian}

Variabel alternatif memilih merupakan variabel terikat atau variabel dependen yang merupakan tipe variabel yang dijelaskan atau dipengaruhi variabel independen yaitu program nabung saham dan reksadana variabel bebas / independen.

Tabel: Defenisi Operasional Variabel

\begin{tabular}{|c|ll|c|}
\hline Variabel & \multicolumn{1}{|c|}{ Indikator } & $\begin{array}{c}\text { Skala } \\
\text { Pengukuran }\end{array}$ \\
\hline Nabung & 1. & Kampanye & \\
Saham & 2. & Persusasi Masyarakat & Ordinary \\
Reksadana & 3. & Fasilitas Online Trading & \\
(X1) & & & \\
\hline Memilih & 1. & Inflasi & Ordinary \\
alternatif & 2. & Jangka Waktu & \\
Investasi (X2) & 3. & Nilai Investasi \\
& 4. & Pengembalian Investasi & \\
\hline
\end{tabular}


ISLAMIC BANKING: Jurnal Pemikiran dan Pengembangan Perbankan Syariah, Volume 7 Nomor 2 Edisi Februari 2022

\begin{tabular}{|c|l|l|}
\hline & 5. Pendapatan Pendidikan & \\
\hline $\begin{array}{c}\text { Peningkatan } \\
\begin{array}{c}\text { Pendapatan } \\
(Y)\end{array}\end{array}$ & $\begin{array}{l}\text { 1. Capital Gain } \\
\text { 2. Dividen }\end{array}$ & Ordinary \\
\hline
\end{tabular}

\section{Uji Instrumen}

Pengujian terhadap hasil kuesioner digunakan analisis-analisis sebagai berikut:

\section{Uji Validitas}

Uji validitas dilakukan untuk memastikan bahwa masing-masing pertanyaan akan terklarifikasi pada variabel-variabel yang telah ditentukan. Pengujian pada penelitian ini menggunakan uji dua sisi dengan taraf signifikansi 0,05 (Ghozali, 2013)

\section{Uji Reliabilitas}

Uji reliabilitas dilakukan dengan menghitung Cronbach's alpha dari masing-masing instrumen dalam suatu variabel. Instrumen yang dipakai dikatakan andal (reliable) jika memiliki nilai Cronbach's alpha lebih dari 0,6.

\section{Teknik Analisis Data}

\section{Uji Asumsi Klasik}

Uji ini meliputi:

1. Uji Normalitas Data

Model regresi yang baik adalah yang memiliki distribusi data normal atau mendekati normal. Distribusi data yang normal dilihat dari penyebaran data pada sumbu diagonal dari grafik Normal P-Plot (Ghozali 2013).

2. Uji Heteroskedastisitas

Model regresi mensyaratkan tidak terjadi heteroskedastisitas. Salah satu cara untuk mendekati heteroskedastisitas adalah dengan melihat grafik scatter plot antara nilai prediksi variabel terikat (ZPRED) dengan residualnya (SRESID).

3. Uji Multikolinieritas

Salah satu rujukan nilai yang digunakan adalah nilai VIF dibawah 10 . Ghozali (2014:92), model regresi yang baik mensyaratkan tidak terjadinya multikolinieritas. 
246 Z Zakaria Harahap \& Ajabar, PROGRAM “YUK NABUNG SAHAM” DAN REKSADANA DALAM..........

\section{Analisis Korelasi (R)}

Koefisien korelasi menunjukkan besarnya hubungan yang terjadi antara varibel bebas terhadap variabel terikat. Nilai $\mathrm{R}$ berkisar antara 0 sampai 1 , nilai semakin mendekati 1 berarti hubungan yang terjadi semakin kuat, sebalikanya nilai semakin mendekati 0, maka hubungan yang terjadi semakin lemah.

Analisis Regresi Linear Berganda

Persamaan regresi linear berganda yang digunakan dalam penelitian ini adalah:

$$
\mathrm{Y}=\mathrm{a}+\mathrm{b} 1 \mathrm{X} 1+\mathrm{b} 2 \mathrm{X} 2+\mathrm{e}
$$

\section{Teknik Pengujian Hipotesis}

Teknik analisis data yang digunakan penulis adalah analisis data kuantitatif dengan bantuan statistik menggunakan aplikasi SPSS. Hipotesis yang digunakan penulis akan diuji dengan menggunakan teknik Analisis regresi linear berganda, Uji t, Uji F dan analisis koefisien determinasi $\left(\mathrm{R}^{2}\right)$

\section{Indikator Memilih Alternatif Investasi}

Menurut Amin dan Mustika (2017) Selain resiko hal lain yang harus diperhatikan dalam memilih alternatif investasi yang ideal yaitu :

a. Inflasi

Adalah indikator untuk melihat tingkat perubahan, dan dianggap terjadi jika proses kenaikan harga berlangsung secara terus-menerus dan saling pengaruhmempengaruhi.

b. Jangka waktu

Adalah jatuh tempo pinjaman atau investasi jangka pendek dan investasi jangka panjang, untuk investasi jangka pendek biasanya dibawah satu tahun, sedangkan investasi jangka panjang yaitu satu sampai empat puluh tahun.

c. Nilai Investasi

Adalah nilai dari suatu perusahaan atau saham (business interest) atau kepentingan dalam perusahaan yang bersifat spesifik terhadap seorang investor, didasarkan pada atau terkait dengan persyaratan tertentu dari seorang atau kelompok investor. 
ISLAMIC BANKING: Jurnal Pemikiran dan Pengembangan Perbankan Syariah, Volume 7 Nomor 2 Edisi Februari 2022

\section{d. Pengembalian investasi}

Pengembalian (return) adalah keuntungan yang akan di dapat pada masa yang akan datang. Pengembalian (return) investasi dapat dibedakan menjadi dua jenis yaitu return yang diharapkan (expected return) dan return yang sebenarnya (realized return).

e. Pendapatan

Pendapatan atau gaji menurut Mulyadi (2008:373) adalah pembayaran atas penyerahan jasa yang dilakukan oleh karyawan administrasi atau yang mempunyai jenjang jabatan manager yang ada pada umumnya dibayarkan secara tetap perbulan.

f. Pendidikan

Pendidikan adalah bagian yang sangat penting bagi kehidupan, baik diri sendiri dan lingkungan. Pendidikan mempengaruhi tingkat kedewasaan sesorang, jadi dalam hal ini tingkat pendidikan juga mempengaruhi terhadap pemilihan investasi yang ideal.

\section{Indikator Peningkatan Pendapatan}

Menurut Cisasti dan Darma (2020) Pada dasarnya, ada 2 (dua) keuntungan yang diperoleh investor dengan membeli atau memiliki saham yaitu Dividen dan Capital Gain. Dividen merupakan pembagian keuntungan yang diberikan perusahaan dan berasal dari keuntungan yang dihasilkan perusahaan. Dividen diberikan setelah mendapat persetujuan dari pemegang saham dalam RUPS. Kemudian Capital Gain merupakan selisih antara harga beli dan harga jual. Capital Gain terbentuk dengan adanya aktivitas perdagangan saham di pasar sekunder.

Menurut laporan Organisation for Economic Co-operation and Development (OECD), yang dikutip dari (Pakpahan, 2020), pandemi Covid-19 ini berimplikasi terhadap ancaman krisis ekonomi besar yang ditandai dengan terhentinya aktivitas produksi di banyak negara, jatuhnya tingkat konsumsi masyarakat, hilangnya kepercayaan konsumen, jatuhnya bursa saham yang pada akhirnya mengarah kepada ketidakpastian. 


\section{Hasil Penelitian}

\section{Karakteristik Umum Responden}

Kuesioner yang disebarkan untuk 99 responden, semua kuesioner memenuhi kriteria. Karakteristik responden yang menjadi subjek dalam penelitian ini terdiri dari jenis kelamin, usia, pendidikan, dan pendapatan. Dalam kuesioner responden tidak perlu mencantumkan identitas pribadi atau nama untuk kerahasiaan informasi yang diberikan responden. Karakteristik responden adalah penjelasan tentang keberadaan responden di Kota Prabumulih, yang dibutuhkan sebagai bahan informasi untuk mengetahui identitas responden dalam penelitian ini.

\section{Hasil Analisis Data}

1. Uji Validitas

Uji Validitas digunakan untuk mengukur sah atau valid tidaknya kuesioner. Suatu kuesioner dikatakan valid jika pertanyaan pada kuesioner mampu untuk mengungkapakan sesuatu yang akan diukur oleh kuesioner tersebut Imam Ghozali, (2011:52). Pengujian validita selengkapnya dapat dilihat padaTabel berikut ini:

Tabel: Hasil Uji Validitas Variabel Nabung Saham Reksadana (X1)

\section{Item-Total Statistics}

\begin{tabular}{|l|r|r|r|r|}
\hline & $\begin{array}{c}\text { Scale Mean if } \\
\text { Item Deleted }\end{array}$ & $\begin{array}{c}\text { Scale Variance } \\
\text { if Item Deleted }\end{array}$ & $\begin{array}{c}\text { Corrected } \\
\text { Item-Total } \\
\text { Correlation }\end{array}$ & $\begin{array}{c}\text { Cronbach's } \\
\text { Alpha if Item } \\
\text { Deleted }\end{array}$ \\
\hline NS1 & 37.61 & 21.547 & .505 & .847 \\
NS2 & 37.48 & 22.191 & .473 & .849 \\
NS3 & 37.44 & 21.474 & .549 & .843 \\
NS4 & 37.43 & 21.432 & .510 & .846 \\
NS5 & 37.61 & 20.915 & .580 & .841 \\
NS6 & 37.68 & 19.527 & .659 & .833 \\
NS7 & 37.53 & 19.680 & .719 & .828 \\
NS8 & 37.38 & 21.280 & .519 & .846 \\
NS9 & 37.23 & 22.201 & .419 & .853 \\
NS10 & 37.61 & 18.690 & .670 & .833 \\
\hline
\end{tabular}

Berdasarkan hasil uji validitas pada Tabel di atas dapat diketahui bahwa variabel Nabung Saham Reksadana (X1) dengan indikator berkorelasi signifikan dengan total skor, ditunjukan nilai $r_{\text {hitung }}>$ dari $r_{\text {tabel}}$. Korelasi yang signifikan antara skor indikator 
ISLAMIC BANKING: Jurnal Pemikiran dan Pengembangan Perbankan Syariah, Volume 7 Nomor 2 Edisi Februari 2022

dengan total skor menunjukan bahwa indikator yang digunakan baik dari variabel bebas $\left(\mathrm{X}_{1}\right)$ dapat mengukur variabel yang diteliti, semua indikator yang digunakan untuk mengukur variabel-variabel yang digunakan dalam penelitian ini mempunyai nilai korelasi yang lebih besar dari 0,202. Dari hasil tersebut menunjukkan bahwa semua indikator tersebut adalah valid.

2. Uji Validitas Variabel Memilih Alternatif Investasi $\left(\mathrm{X}_{2}\right)$

Kuesioner dikatakan valid apabila item pertanyaan kuesioner mampu mengungkapkan sesuatu yang akan diukur. Uji validitas dalam penelitian ini menggunakan nilai korelasi product moment (r). Item pertanyaan dinyatakan valid apabila nilai $r$ hitung > $r$ tabel. Hasil uji dapat dilihat pada tabel berikut:

Tabel: Hasil Uji Validitas Variabel Memilih Alternatif Investasi (X2)

\begin{tabular}{|l|r|r|r|r|}
\hline \multicolumn{5}{|c|}{ Item-Total Statistics } \\
\hline & $\begin{array}{c}\text { Scale Mean if } \\
\text { Item Deleted }\end{array}$ & $\begin{array}{r}\text { Scale Variance } \\
\text { if Item Deleted }\end{array}$ & $\begin{array}{c}\text { Corrected } \\
\text { Item-Total } \\
\text { Correlation }\end{array}$ & $\begin{array}{c}\text { Cronbach's } \\
\text { Alpha if Item } \\
\text { Deleted }\end{array}$ \\
\hline MA1 & 37.31 & 17.952 & .376 & .740 \\
MA2 & 37.12 & 18.842 & .358 & .742 \\
MA3 & 37.25 & 18.109 & .448 & .730 \\
MA4 & 37.04 & 17.958 & .432 & .732 \\
MA5 & 37.23 & 17.976 & .410 & .735 \\
MA6 & 37.35 & 17.251 & .472 & .726 \\
MA7 & 37.27 & 17.180 & .522 & .719 \\
MA8 & 37.01 & 18.459 & .356 & .742 \\
MA9 & 36.92 & 18.708 & .341 & .744 \\
MA10 & 37.39 & 16.527 & .453 & .730 \\
\hline
\end{tabular}

Hasil uji validitas pada Tabel di atas dapat diketahui bahwa variabel Memilih Alternatif Investasi $\left(\mathrm{X}_{2}\right)$ dengan indikator berkorelasi signifikan dengan total skor, ditunjukan nilai $r_{\text {hitung }}>$ dari $r_{\text {tabel. }}$. Korelasi yang signifikan antara skor indikator dengan total skor menunjukan bahwa indikator yang digunakan baik dari variabel bebas $\left(\mathrm{X}_{2}\right)$ dapat mengukur variabel yang diteliti, semua indikator yang digunakan untuk mengukur variabel-variabel yang digunakan dalam penelitian ini mempunyai nilai 
korelasi yang lebih besar dari 0,202. Dari hasil tersebut menunjukkan bahwa semua indikator tersebut adalah valid.

3. Uji Validitas Variabel Tingkat Peningkatan Pendapatan (Y)

Kuesioner dikatakan valid apabila item pertanyaan kuesioner mampu mengungkapkan sesuatu yang akan diukur. Uji validitas dalam penelitian ini menggunakan nilai korelasi product moment (r). Item pertanyaan dinyatakan valid apabila nilai $r$ hitung $>r$ tabel. Hasil uji dapat dilihat pada tabel berikut:

Tabel: Hasil Uji Validitas Variabel Peningkatan Pendapatan (Y)

Item-Total Statistics

\begin{tabular}{|l|r|r|r|r|}
\hline & $\begin{array}{c}\text { Scale Mean if } \\
\text { Item Deleted }\end{array}$ & $\begin{array}{c}\text { Scale Variance } \\
\text { if Item Deleted }\end{array}$ & $\begin{array}{c}\text { Corrected } \\
\text { Item-Total } \\
\text { Correlation }\end{array}$ & $\begin{array}{c}\text { Cronbach's } \\
\text { Alpha if Item } \\
\text { Deleted }\end{array}$ \\
\hline PP1 & 39.36 & 14.887 & .677 & .700 \\
PP2 & 39.32 & 15.241 & .619 & .710 \\
PP3 & 38.86 & 17.163 & .486 & .734 \\
PP4 & 38.78 & 18.379 & .335 & .752 \\
PP5 & 39.47 & 15.701 & .349 & .763 \\
PP6 & 39.03 & 16.744 & .461 & .736 \\
PP7 & 39.03 & 17.397 & .380 & .746 \\
PP8 & 38.70 & 17.846 & .421 & .743 \\
PP9 & 38.70 & 18.622 & .333 & .753 \\
PP10 & 39.20 & 16.489 & .327 & .760 \\
\hline
\end{tabular}

Sumber : Data Primer Penelitian Diolah, 2021.

Hasil uji validitas pada Tabel di atas dapat diketahui bahwa variabel Peningkatan Pendapatan (Y) dengan indikator berkorelasi signifikan dengan total skor, ditunjukan nilai $r_{\text {hitung }}>$ dari $r_{\text {tabel. }}$. Korelasi yang signifikan antara skor indikator dengan total skor menunjukan bahwa indikator yang digunakan baik dari variabel terikat (Y) dapat mengukur variabel yang diteliti, semua indikator yang digunakan untuk mengukur variabel-variabel yang digunakan dalam penelitian ini mempunyai nilai korelasi yang lebih besar dari 0,202 dari hasil tersebut menunjukkan bahwa semua indikator tersebut adalah valid.

\section{Reliabilitas}

Pengujian reliabilitas dengan metode Alpha Cronbach adalah dengan membandingkan koefisien Alpha $(\alpha)$ dengan 0,6. Jika koefisien Alpha ( $\mathrm{r}_{\text {hitung }}$ ) > 0,6 
ISLAMIC BANKING: Jurnal Pemikiran dan Pengembangan Perbankan Syariah, Volume 7 Nomor 2 Edisi Februari 2022

maka item tersebut reliabel, sedangkan jika koefisien Alpha $\left(\mathrm{r}_{\text {hitung }}\right)<0,6$, maka item tersebut tidak reliabel (Arikunto 2011:75).

Pengujian reliabilitas dalam penelitian ini adalah dengan menggunakan rumus Cronbach Alpha. Hasil pengujian reliabilitas untuk masing-masing variabel yang diringkas pada tabel-tabel hasil uji reliabilitas berikut ini:

Tabel: Rangkuma Hasil Pengujian Reliabilitas

\begin{tabular}{|l|c|c|}
\hline \multicolumn{1}{|c|}{ Variabel } & Alpha & Ketererangan \\
\hline Nabung Saham Reksa Dana $\left(\mathrm{X}_{1}\right)$ & 0,856 & Reliabel \\
\hline Memilih alternatif Investasi $\left(\mathrm{X}_{2}\right)$ & 0,754 & Reliabel \\
\hline Peningkatan Pendapatan $(\mathrm{Y})$ & 0,760 & Reliabel \\
\hline
\end{tabular}

Sumber : Data primer yang diolah 2021

Hasil uji reliabilitas seperti output SPSS tersebut pada tabel di atas, menunjukan bahwa semua variabel mempunyaii koefisien Alpha yang lebih besar dari 0,6 sehingga dapat dikatakan semua konsep pengukur masing-masing variabel dari kuesioner adalah reliabel.

\section{Uji Asumsi Klasik}

Suatu model regresi yang baik harus memenuhi tidak adanya masalah asumsi klasik dalam modelnya. Jika masih terdapat asumsi klasik maka model regresi tersebut masih memiliki bias. Jika suatu model masih terdapat adanya masalah asumsi klasik, maka akan dilakukan langkah revisi model ataupun penyembuhan untuk menghilangkan masalah tersebut. Pengujian asumsi klasik akan dilakukan berikut :

1. Uji Normalitas

Uji Normalitas dipergunakan untuk melihat apakah sebaran data hasil penelitian terdistribusi secara normal atau tidak. Uji normalitas dilakukan dengan cara Normal P-P Plot. Dasar pengambilan keputusan menurut Ghozali (2010:106-110) :

a. Jika data menyebar di sekitar garis diagonal dan mengikuti arah garis diagonal atau grafik histogramnya menunjukkan pola distribusi normal, maka model regresi memenuhi asumsi normalitas. 
b. Jika data menyebar jauh dari garis diagonal dan tidak mengikuti arah diagonal atau grafik histogram tidak menunjukkan pola distribusi normal maka model regresi tidak memenuhi asumsi normalitas.

Hasil analisis regresi linier dengan grafik normal P-P Plot terhadap residual error model regresi diperoleh sudah menunjukan adanya pola grafik yang normal, yaitu:

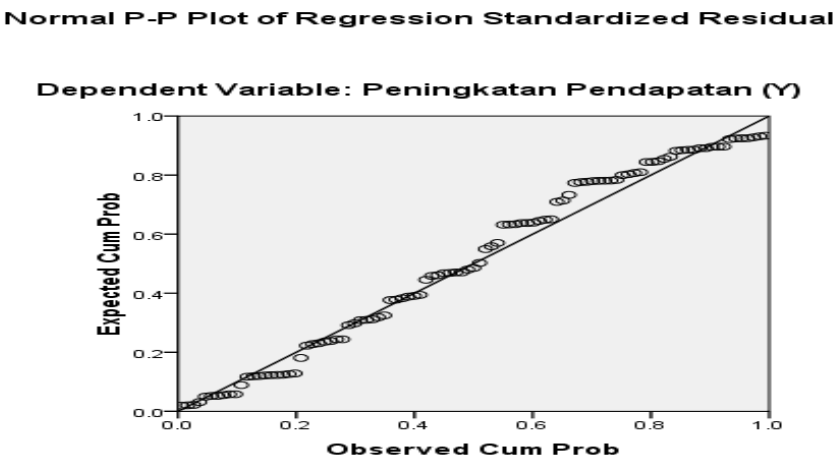

Gambar:

Pengujian Normalitas

Hasil pengujian tersebut menunjukan bahwa titik-titik berada tidak jauh dari garis diagonal. Hal ini berarti bahwa model regresi tersebut sudah terdistribusi normal 2. Pengujian Heteroskedastisitas

Pengujian heterokedastisitas bertujuan untuk mengetahui apakah dalam model regresi terjadi ketidaksamaan varians dari residual pengamatan yang lain. Hasil uji heterokedastisitas ditunjukan pada gambar berikut

Scatterplot

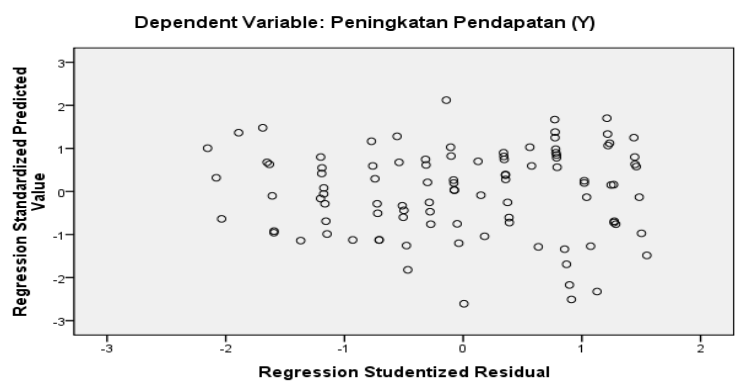

Gambar: Grafik Uji Heteroskedastisitas

Sumber: Data primer diolah, 2021 
ISLAMIC BANKING: Jurnal Pemikiran dan Pengembangan Perbankan Syariah, Volume 7 Nomor 2 Edisi Februari 2022

Dari gambar grafik di atas dapat diketahui bahwa titik-titik menyebar dengan pola yang tidak jelas di atas dan di bawah angka 0 pada sumbu Y. Jadi disimpulkan bahwa tidak terjadi masalah heteroskedastisitas pada model regresi.

\section{Analisa Korelasi}

Analisis korelasi bertujuan untuk mengetahui hubungan antara variabel bebas bebas dan variabel terikat. Hasil perhitungan korelasi pada Tabel di bawah ini dapat diinterprestasikan sebagai berikut :

Tabel: Hasil Uji Korelasi

\begin{tabular}{|c|c|c|c|c|c|c|}
\hline \multicolumn{7}{|c|}{ Correlations } \\
\hline & & & $\begin{array}{c}\text { Nabung } \\
\text { Saham } \\
\text { Reksadana } \\
\text { (X1) }\end{array}$ & $\begin{array}{l}\text { Memilih } \\
\text { Alternatif } \\
\text { Investasi } \\
\text { (X2) }\end{array}$ & $\begin{array}{c}\text { Peningkatan } \\
\text { Pendapatan } \\
\text { (Y) }\end{array}$ & $\begin{array}{c}\text { Unstandardized } \\
\text { Residual }\end{array}$ \\
\hline \multirow{12}{*}{$\begin{array}{l}\text { Spearman' } \\
\text { s rho }\end{array}$} & \multirow{3}{*}{$\begin{array}{l}\text { Nabung Saham } \\
\text { Reksadana (X1) }\end{array}$} & Correlation Coefficient & 1.000 & .084 & .047 & .061 \\
\hline & & Sig. (2-tailed) & & .571 & .584 & .730 \\
\hline & & $\mathrm{N}$ & 100 & 100 & 100 & 100 \\
\hline & \multirow{3}{*}{$\begin{array}{l}\text { Memilih Alternatif } \\
\text { Investasi (X2) }\end{array}$} & Correlation Coefficient & .084 & 1.000 & $.611^{* *}$ & .072 \\
\hline & & Sig. (2-tailed) & .571 & & .000 & .826 \\
\hline & & $\mathrm{N}$ & 84 & 84 & 84 & 84 \\
\hline & \multirow{3}{*}{$\begin{array}{l}\text { Peningkatan } \\
\text { Pendapatan }(\mathrm{Y})\end{array}$} & Correlation Coefficient & .047 & $.611^{\star \star}$ & 1.000 & -.037 \\
\hline & & Sig. (2-tailed) & .584 & .000 & & .475 \\
\hline & & $\mathrm{N}$ & 84 & 84 & 84 & 84 \\
\hline & \multirow{3}{*}{$\begin{array}{l}\text { Unstandardized } \\
\text { Residual }\end{array}$} & Correlation Coefficient & .061 & .072 & -.037 & 1.000 \\
\hline & & Sig. (2-tailed) & .730 & .826 & .475 & \\
\hline & & $\mathrm{N}$ & 84 & 84 & 84 & 84 \\
\hline
\end{tabular}

${ }^{* *}$. Correlation is significant at the 0.01 level (2-tailed).

Berdasarkan hasil perhitungan statistik computer, diperoleh nilai korelasi Nabung Saham Reksadana $\left(\mathrm{X}_{1}\right)$, memilih alternatif Investasi $\left(\mathrm{X}_{2}\right)$ terhadap variabel terikat Peningkatan Pendapatan (Y). Hasil perhitungan korelasi pada Tabel di atas dapat diinterprestasikan sebagai berikut :

- $\quad$ Keeratan hubungan variabel dapat diketahui nilai korelasi antara variabel Nabung Saham Reksadana $\left(X_{1}\right)$ sebesar 0,730, karena berada di range 0,600-0,799, maka disimpulkan bahwa hubungan variabel $\left(\mathrm{X}_{1}\right)$ Nabung Saham Reksadana adalah kuat, sedang hubungan positif karena nilai korelasi positif.

- Keeratan hubungan variabel Memilih Alternatif Investasi dapat diketahui nilai korelasi antara variabel Memilih Alternatif Investasi $\left(\mathrm{X}_{2}\right)$ sebesar 0,826, karena berada di range 0,600-0,799, maka disimpulkan bahwa hubungan variabel $\left(\mathrm{X}_{2}\right)$ 
Memilih Alternatif Investasi adalah sedang, sedang hubungan positif karena nilai korelasi positif.

- $\quad$ Keeratan hubungan variabel peningkatan pendapatan dapat diketahui nilai korelasi antara variabel peningkatan pendapatan (Y) sebesar 0,475, karena berada di range 0,400 - 0,599 maka disimpulkan bahwa hubungan variabel (Y) peningkatan pendapatan adalah sedang hubungan positif karena nilai korelasi positif.

\section{Pengujian Multikolonieritas}

Pengujian multikolonieritas dilakukan dengan menggunakan nilaiVIF suatu variable menunjukan gejala multikolonieritas bias dilihat dari nilai VIF (Variance Inflation Factor) yang tinggi pada variabel-variabel bebas suatu model regresi. Nilai VIF dari variabel bebas pada model regresi adalah sebagai berikut :

Tabel: Hasil Uji Multikolonieritas

\begin{tabular}{|c|c|c|c|c|c|c|c|}
\hline \multicolumn{8}{|c|}{ Coefficients $^{\mathrm{a}}$} \\
\hline \multirow[b]{2}{*}{ Model } & \multicolumn{2}{|c|}{$\begin{array}{l}\text { Unstandardized } \\
\text { Coefficients } \\
\end{array}$} & \multirow{2}{*}{$\begin{array}{c}\begin{array}{c}\text { Standardized } \\
\text { Coefficients }\end{array} \\
\text { Beta } \\
\end{array}$} & \multirow[b]{2}{*}{$t$} & \multirow[b]{2}{*}{ Sig. } & \multicolumn{2}{|c|}{ Collinearity Statistics } \\
\hline & $\mathrm{B}$ & Std. Error & & & & Tolerance & VIF \\
\hline 1 (Constant) & 24.549 & 21.574 & & 6.231 & .000 & & \\
\hline $\begin{array}{l}\text { Nabung Saham } \\
\text { Reksadana } \\
\text { (X1) }\end{array}$ & .718 & 204 & .482 & 2.289 & .003 & 692 & 2.401 \\
\hline $\begin{array}{l}\text { Memilih } \\
\text { Alternatif } \\
\text { Investasi (X2) }\end{array}$ & .683 & .526 & .661 & 2.014 & .001 & 292 & 2.357 \\
\hline
\end{tabular}

a. Dependent Variable: Peningkatan Pendapatan (Y)

Berdasarkan tabel diatas nilai tolerance semua variabel bebas (Nabung Saham Reksadana 0,692, memilih alternatif investasi 0,292, lebih besar dari nilai batas yang ditentukan yaitu sebesar 0,004. Untuk nilai VIF terlihat bahwa semua variabel bebas memiliki nilai VIF yang kurang dari 10 (Nabung Saham Reksadana 2,401, memilih alternatif investasi 2.357). Maka dapat disimpulkan tidak terdapat gejala multikolinieritas antar variabel bebas dalam penelitian ini.

\section{Analisis Regresi Linear Berganda}

Perhitungan statistik dalam analisis regresi linear berganda yang digunakan dalam penelitian ini adalah dengan menggunakan bantuan program computer SPSS. Hasil 
ISLAMIC BANKING: Jurnal Pemikiran dan Pengembangan Perbankan Syariah, Volume 7 Nomor 2 Edisi Februari 2022

pengolahan data selengkapnya ada pada lampiran dan selanjutnya akan dijelaskan pada tabel berikut :

Tabel: Hasil Uji Regresi

Coefficients $^{\mathrm{a}}$

\begin{tabular}{|c|c|c|c|c|c|c|}
\hline \multirow[b]{2}{*}{ Model } & & \multicolumn{2}{|c|}{ Unstandardized Coefficients } & \multirow{2}{*}{$\begin{array}{c}\begin{array}{c}\text { Standardized } \\
\text { Coefficients }\end{array} \\
\text { Beta }\end{array}$} & \multirow[b]{2}{*}{$\mathrm{t}$} & \multirow[b]{2}{*}{ Sig. } \\
\hline & & B & Std. Error & & & \\
\hline 1 & (Constant) & 24.549 & 21.574 & & 6.231 & .000 \\
\hline & $\begin{array}{l}\text { Nabung Saham } \\
\text { Reksadana (X1) }\end{array}$ & .718 & .204 & .482 & 2.895 & .003 \\
\hline & $\begin{array}{l}\text { Memilih Alternatif } \\
\text { Investasi (X2) }\end{array}$ & .683 & .526 & .661 & 2.014 & .001 \\
\hline
\end{tabular}

Model persamaan regresi yang dapat dituliskan dari hasil tersebut dalam bentuk persamaan regresi sebagai berikut :

$\mathrm{Y}=24.549+0,718 \mathrm{X} 1+0,683 \mathrm{X} 2+\mathrm{e}$

Persamaan regresi tersebut dapat dijelaskan sebagai berikut :

a. $\quad$ Nilai koefisien regresi konstanta $=24.549$ dengan tanda positif yang merupakan nilai konstanta dimana diartikan bahwa jika variabel-variabel independen yaitu Nabung Saham Reksadana, Memilih alternatif Investasi dan tingkat pendidikan diasumsikan dengan nilai konstan, maka variabel dependen yaitu kepatuhan wajib pajakakan sebesar 24.549

b. Nilai koefisien regresi X1 (b1) sebesar 0,718 artinya untuk setiap kenaikan 1 skor variabel Nabung Saham Reksadana (X1) akan menaikkan skor peningkatan pendapatan (Y) sebesar 0,718 .

c. Nilai koefisien regresi X2 (b2) sebesar 0,683 artinya untuk setiap kenaikan 1 skor variabel Memilih alternatif Investasi (X2) akan menaikkan skor Peningkatan Pendapatan (Y) sebesar 0,683.

Dari hasil koefisien regresi berganda yang telah dijelaskan pada uarain di atas selanjutnya akan dilakukan pengujian hipotesis yang dilakukan secara parsial maupun simultan. 


\section{Uji Hipotesis}

Pengujian hipotesis dalam penelitian bertujuan untuk membuktikan pengaruh Nabung Saham Reksadana, Memilih alternatif Investasi terhadap peningkatan pendapatan UKM Kota Prabumulih. Adapun tabel hasil uji t dan pengujian hipotesis disajikan pada tabel

\section{Uji t (secara parsial)}

Penjelasan hasil uji untuk masing-masing variabel bebas adalah sebagai berikut:

Diketahui untuk pengaruh variabel X1 terhadap Y adalah nilai t hitung $2.895>$ nilai t tabel 1.985. berdasarkan analisis pengaruh variabel independen (Nabung Saham Reksa Dana X1) terhadap variabel dependen (peningkatan pendapatan) berpengaruh positif, dapat dilihat dari nilai t hitung lebih besar dari nilai t tabel, dengan signifikansi $0,003<0,05$ maka H1 diterima berarti terdapat pengaruh antara Nabung Saham Reksadana terhadap peningkatan pendapatan.

Diketahui untuk pengaruh variabel X2 terhadap Y adalah nilai t hitung $2.014>$ nilai $\mathrm{t}$ tabel 1.985. berdasarkan analisis pengaruh variabel independen (Memilih alternatif Investasi, X2) terhadap variabel dependen (peningkatan pendapatan) berpengaruh positif, dapat dilihat dari nilai $t$ hitung lebih besar dari nilai $t$ tabel, dengan signifikansi $0,001<0,05$ maka $\mathrm{H} 2$ diterima berarti terdapat pengaruh antara Memilih alternatif Investasi terhadap peningkatan pendapatan.

\section{Uji F (Simultan)}

Uji F digunakan untuk melihat signifikan tidaknya hubungan variabel independen dengan variabel mediasi secara bersama-sama dan untuk melihat signifikan tidaknya hubungan variabel independen dengan variabel dependen secara bersama-sama, sedangkan koefisien beta digunakan untuk melihat arah hubungan pengaruh variabel independen terhadap variabel dependen. Dasar penelitian ini adalah menurut Ghozali (2011:56). Hasil perhitungan regresi secara bersama-sama diperoleh pada Tabel berikut: 
ISLAMIC BANKING: Jurnal Pemikiran dan Pengembangan Perbankan Syariah, Volume 7 Nomor 2 Edisi Februari 2022

Tabel: Hasil Analisis Regresi Secara Bersama-sama

ANOVA $^{\mathrm{a}}$

\begin{tabular}{|ll|r|r|r|r|r|}
\hline Model & & Sum of Squares & \multicolumn{1}{|c|}{$\mathrm{df}$} & Mean Square & $\mathrm{F}$ & Sig. \\
\hline 1 & Regression & 45.347 & 3 & 15.116 & 5.278 & $.004^{\mathrm{b}}$ \\
& Residual & 1678.225 & 80 & 20.978 & & \\
& Total & 1723.571 & 83 & & & \\
\hline
\end{tabular}

a. Dependent Variable: Peningkatan Pendapatan (Y)

Hasil perhitungan statistik menunjukan nilai Fhitung $=5,278>$ Ftabel $=$ 2.750 dengan signifikansi sebesar $0,004<0,05$ Dengan nilai signifikansi dibawah 0,05 dan Fhitung > Ftabel menunjukan bahwa secara bersama-sama Nabung Saham Reksadana, Memilih alternatif Investasi.

Hasil perhitungan statistik menunjukan nilai Fhitung $=5,278>$ Ftabel $=$ 2.750 dengan signifikansi sebesar 0,004 $<0,05$ Dengan nilai signifikansi dibawah 0,05 dan Fhitung > Ftabel menunjukan bahwa secara bersama-sama Nabung Saham Reksadana, Memilih alternatif Investasi mempunyai pengaruh yang positif dan signifikan terhadap peningkatan pendapatan, hal ini berarti hipotesis diterima

\section{Koefisien Determinasi}

Hasil dari pengolahan data yang menggunakan bantuan program SPSS ,juga menghasilkan output berupa tabel koefisien model summary. Analisis koefisien determinasi ini menghasilkan gambaran seberapa signifikan pengaruh secara simultan variabel indevenden nabung saham reksadana, memilih alternatif Investasi terhadap peningkatan pendapatan seperti terlihat pada Tabel berikut:

\section{Tabel: Koefisien Determinasi}

\section{Model Summary}

\begin{tabular}{|l|r|r|r|c|}
\hline Model & $\mathrm{R}$ & $\mathrm{R}$ Square & $\begin{array}{c}\text { Adjusted R } \\
\text { Square }\end{array}$ & $\begin{array}{c}\text { Std. Error of the } \\
\text { Estimate }\end{array}$ \\
\hline 1 & $.742^{\mathrm{a}}$ & .836 & .696 & 4.58015 \\
\hline
\end{tabular}

a. Predictors: (Constant), Memilih alternatif Investasi (X2), Nabung

Saham Reksadana (X1)

b. Dependent Variable: Peningkatan Pendapatan (Y) 
Dari outputmodel summary didapatkan tabel determinasi di atas yang Memberikan $R$ Square sebesar 0,836. Hal ini menunjukan bahwa variabel Nabung Saham Reksadana, Memilih alternatif Investasi secara simultan persentase sumbangan pengaruh variabel independen mempunyai pengaruh terhadap variabel dependen (peningkatan pendapatan), sebesar 16,4\%. Atau variabel independen (Nabung Saham Reksadana, Memilih alternatif Investasi) mampu menjelaskan sebesar 83,6\% terhadap variabel dependen (peningkatan pendapatan), sedangkan sisanya 16,4\% dipengaruhi atau dijelaskan oleh variabel lain yang tidak diteliti dalam penelitian ini.

\section{Simpulan}

Berdasarkan hasil penelitian seperti yang telah diuraikan pada bab sebelumnya, dapat ditarik kesimpulan yaitu:

1. Dilihat dari hasil uji untuk pengaruh variabel Nabung Saham Reksadana (X1) terhadap Peningkatan Pendapatan (Y) Diketahui untuk pengaruh variabel X1 terhadap Y adalah nilai t hitung $2.895>$ nilai t tabel 1.985. berdasarkan analisis pengaruh variabel independen (Nabung Saham Reksa Dana X1) terhadap variabel dependen (peningkatan pendapatan) berpengaruh positif, dapat dilihat dari nilai $\mathrm{t}$ hitung lebih besar dari nilai t tabel, dengan signifikansi $0,003<0,05$ maka H1 diterima berarti terdapat pengaruh antara Nabung Saham Reksadana terhadap peningkatan pendapatan.

2. Dilihat dari hasil uji untuk pengaruh variabel memilih alternatif investasi (X2) terhadap peningkatan pendapatan (Y) Diketahui untuk pengaruh variabel X2 terhadap Y adalah nilai t hitung $2.014>$ nilai t tabel 1.985. berdasarkan analisis pengaruh variabel independen (Memilih alternatif Investasi, X2) terhadap variabel dependen (peningkatan pendapatan) berpengaruh positif, dapat dilihat dari nilai t hitung lebih besar dari nilai t tabel, dengan signifikansi 0,001 0,05 maka H2 diterima berarti terdapat pengaruh antara Memilih alternatif Investasi terhadap peningkatan pendapatan.

3. Hasil perhitungan statistik menunjukan nilai Fhitung $=5,278>$ Ftabel $=2.750$ dengan signifikansi sebesar 0,004 $<0,05$ Dengan nilai signifikansi dibawah 0,05 dan Fhitung > Ftabel menunjukan bahwa secara bersama-sama Nabung Saham 
ISLAMIC BANKING: Jurnal Pemikiran dan Pengembangan Perbankan Syariah, Volume 7 Nomor 2 Edisi Februari 2022

Reksadana, Memilih alternatif Investasi mempunyai pengaruh yang positif dan signifikan terhadap peningkatan pendapatan, hal ini berarti hipotesis diterima

\section{Saran}

Berdasarkan kesimpulan di atas, dapat diusulkan saran yang diharapkan akan bermanfaat bagi penelitian selanjutnya:

1. Berdasarkan masalah Nabung Saham Reksadana maka peneliti menyarankan pihak manajemen Reksadana, dapat meningkatkan sosialisasi dan workshop tentang saham untuk meningkatkan pemahaman dan pengetahuan mengenai saham.

2. Berdasarkan memilih alternatif Investasi maka peneliti menyarankan pihak investor, masyarakat umum untuk lebih teliti dalam menanamkan modal dan bisa mengetahui cara-cara memvaluasi saham terhadap perusahaan yang tergabung di pasar modal.

3. Dengan keadaan ekonomi global yang tidak sehat seperti saat ini, perusahaan perusahaan dapat menambah jumlah sahamnya yang beredar di publik sehingga bisa menambah kepercayaan investor akan komitmen perusahaan terhadap penerapan good corporate governance. Hal ini akan membantu perusahaan memperoleh dana segar dalam rangka mewujudkan target.

4. Bagi Peneliti Selanjutnya

Untuk saran bagi peneliti berikutnya yang akan membahas mengenai saham agar dapat mengumpulkan data-data spesifik perusahaan terutama mengenai strategi pertumbuhan perusahaan dimasa depan melalui wawancara langsung dengan pihak perusahaan. Hasil dari wawancara tersebut akan lebih memaksimalkan asumsi peneliti dalam melakukan forecasting. 


\section{DAFTAR PUSTAKA}

Anoraga, P., dan Pakarti, P. (2006). Pegantar Pasar Modal. Jakarta: Rineka Cipta

Amin, Ruhul, \& Mustika, Wida Prima. (2017). Model Pengambilan Keputusan Berbasis Kriteria Majemuk Dalam Pemilihan Investasi Ideal Bagi Masyarakat, Journal Industrial Servicess Vol. 3 No. 1b Oktober 2017

Baker, T., \& Judge, K. (2020). How to Help Small Businesses Survive COVID-19. Columbia Law and Economics Working Paper (620). Retrieved from http://dx.doi.org/10.2139/ssrn.3571460

Cisasti, Ni Nyoman, \& Darma, Gede Sari. (2020). Menakar Asa Optimalisasi Profit Melalui Konsep "Yuk Nabung Saham", E-Jurnal Manajemen, Vol. 9, No. 8, 2020 : 3169-3192

Darmadji, T., \& Fakhruddin, H. M. (2012). Pasar Modal Di Indonesia. Salemba Empat

Ermawati. N., Tutik Khotimah, Ratih Nindyasari. (2019). Faktor-Faktor Yang Mempengaruhi Usaha Mikro Kecil Menengah (Umkm) Dalam Pengambilan Keputusan Investasi Studi Kasus Pada Umkm Batik Tulis Lasem. Prosiding SENDI_U 2019 Hal. 547-552 ISBN: 978-979-3649-99-3

Fahmi, I. (2012). Pengantar Pasar Modal. Alfabeta.

Ghozali. I. (2013), Aplikasi Analisis Multivariate Dengan Program SPSS, Universitas Diponegoro, Semarang

Umar. H. (2013). Metode Penelitian untuk Skripsi dan Tesis. Jakarta: Rajawali

Merawati, L.K., \& Putra, I.P.M.J.S. (2015). Dampak Pelatihan Pasar Modal Terhadap Pengetahuan Investasi dan Minat Berinvestasi Mahasiswa. Seminar Nasional oleh Lembaga Penelitian Dan Pemberdayaan Masyarakat (LPPM) UNMAS Denpasar

OECD. (2020). SME Policy Responses: Tackling Coronavirus (Covid-19) Contributing to A Global Effort. Retrieved from https://oecd.dambroadcast.com/pm_7379_119_119680-di6h3qgi4x.pdf

Pakpahan, A. K. (2020). COVID-19 dan Implikasi Bagi Usaha Mikro, Kecil, dan Menengah. Jurnal Ilmiah Hubungan Internasional

Prasetyo, A., \& Huda, M. (2019). Analisis Peranan Usaha Kecil dan Menengah Terhadap Penyerapan Tenaga Kerja di Kabupaten Kebumen. Fokus Bisnis: Media Pengkajian Manajemen dan Akuntansi, 18(1), 26-35

Putri, Wilantika Waskito, Hamidi, Masyhuri. (2019). Pengaruh Literasi Keuangan, Efikasi Keuangan, Dan Faktor Demografi Terhadap Pengambilan Keputusan Investasi (Studi Kasus Pada Mahasiswa Magister Manajemen Fakultas Ekonomi Universitas Andalas Padang). Jurnal Ilmiah Mahasiswa Ekonomi Manajemen. Vol. 4, No. 1, Hal 398-412. 
ISLAMIC BANKING: Jurnal Pemikiran dan Pengembangan Perbankan Syariah, Volume 7 Nomor 2 Edisi Februari 2022

Qamruzzaman ACMA (2014). Comparative Study on Performance Evaluation of Mutual Fund Schemes in bangladesh: An Analysis of Monthly Returns. Journal of Business Studies Quarterly, Volume 5, Number 4. 190-209

Rachman, S. (2016). Analisis Pengaruh Perkembangan Usaha Kecil Dan Menengah Sektor Manufaktur Terhadap Pertumbuhan Ekonomi Di Kota Makassar. |Ad'ministrare, Vol. 3 No. 2, 2016, 71-82

Setiawan. (2020). sebanyak 37.000 UMKM Terdampak Virus Corona. Retrieved from https://money.kompas.com/read/2020/04/17/051200426/sebanyak-37.000-umkmterdampakvirus-corona https://bisnis.tempo.co/read/1344540/47-persen-umkmbangkrut-akibat-pandemi-corona

Sugiri. D. (2020). Menyelamatkan Usaha Mikro, Kecil dan Menengah dari Dampak Pandemi Covid-19. Fokus Bisnis: Media Pengkajian Manajemen dan Akuntansi Vol. 19, No. 1, 76-86

Tandio, T. \& Widanaputra, A. A. G. P. (2016). Pengaruh Pelatihan Pasar Modal, Return, Persepsi Risiko, Gender, Dan Kemajuan Teknologi Pada Minat Investasi Mahasiswa. E-Jurnal Akuntansi Universitas Udayana, 16.(3), 2316-2341

Tumewu. T. (2019) Minat Investor Muda Untuk Berinvestasi Di Pasar Modal Melalui Teknologi Fintech, Jurnal Ilmiah Manajemen Bisnis Dan Inovasi Universitas Sam Ratulangi Vol.6 No.2. Mei 2019, Hal.133-146,

Undang-Undang Pasar Modal Nomor 8 Tahun 1995 pasal 1, ayat (27)

Undang-Undang Nomor 20 Tahun 2008

Yusuf Imam Santoso, "Menghitung dampak Covid19 terhadap dunia usaha hingga UMKM,"

Kontan.co.id, diakses $22 \quad$ April 2020, https://nasional.kontan.co.id/news/menghitungdampak-covid-19-terhadap-duniausaha-hinggaumkm?page=all

http://yuknabungsaham.idx.co.id/about-yns Diakses pada 14 Februari 2020

https://bisnis.tempo.co/read/1344540/47-persen-umkm-bangkrut-akibat-pandemi-corona Diakses pada 18 Juli 2021

https://bisnis.tempo.co/read/1398165/kadin-prediksi-jumlah-pengangguran-capai-13juta-orang-akibat-pandemi Diakses pada 22 September 2021

https://www.idx.co.id/investor/pengantar-pasar-modal/ Diakses pada 08 Maret 2021

https://www.kompas.com/tren/read/2020/10/04/064657165/update-covid-19-didunia-4-oktober-351-juta-orang-terinfeksi-1-juta?page=all Diakses pada 28 Agustus 2021 
$262 \mid$ Zakaria Harahap \& Ajabar, PROGRAM "YUK NABUNG SAHAM" DAN REKSADANA DALAM........... 